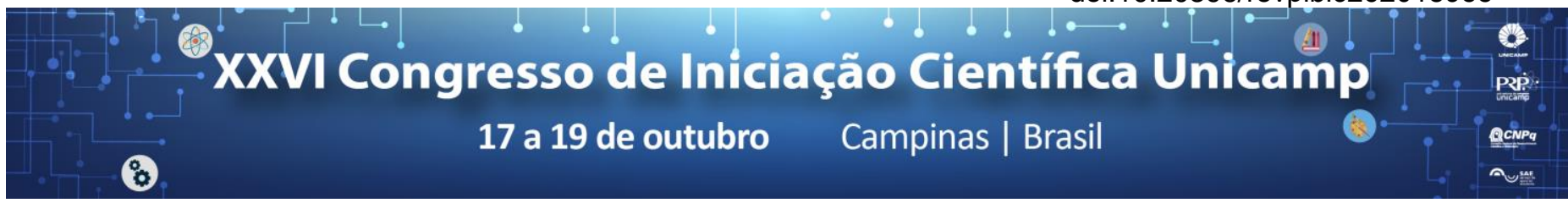

\title{
Projeto de um rastreador usando conceitos de internet das coisas aplicado ao ônibus inteligente.
}

\section{Marcelo Ramos Romano*, Leandro Tiago Manera}

\section{Resumo}

O propósito desse trabalho foi a elaboração do projeto de um circuito que tornasse possível monitorar a posição geográfica do ônibus circular da Universidade Estadual de Campinas (Unicamp). O projeto se deu em várias etapas: elaboração do esquemático com o auxílio de um protoboard, elaboração do layout da placa de circuito impresso, contrução do protótipo e elaboração do software. O projeto utilizou a comunicação Wi-Fi através do microcontrolador ESP8266. O projeto foi bem sucedido, enviando os dados para um servidor próprio do aluno, hospedado na página ThingSpeak. Futuramente os dados serão enviados para o servidor da Prefeitura do Campus da Unicamp.

\section{Palavras-chave:}

Rastreador, IoT, Circular Interno.

\section{Introdução}

Atualmente, o tema Campus Inteligente tem gerado cada vez mais interesse dentro da Universidade Estadual de Campinas (Unicamp). Assim, esse projeto teve como objetivo, em parceria com a Prefeitura do Campus, possibilitar o monitoramento em tempo real da posição do Circular Interno da Unicamp, projeto esse inserido em um projeto maior denominado Smart Campus, que é coordenado por professores da Unicamp e pela Prefeitura do Campus.

\section{Resultados e Discussão}

Para que fosse possível o monitoramento em tempo real do Circular Interno, foi necessária a elaboração de um circuito que fizesse essa função. Em primeiro lugar, fez-se necessária a escolha da comunicação a ser utilizada do com o servidor central da Prefeitura do Campus. Como foi escolhida a comunicação $\mathrm{Wi}-\mathrm{Fi}$, optou-se por utilizar 0 micro controlador ESP8266 no projeto, pois ele possui antena e bibliotecas apropriadas para esse tipo de comunicação'

Além disso, para se monitorar a posição do ônibus, era necessário a utilização de um dispositivo GPS para captar a posição geográfica do ônibus em cada momento. O dispositivo utilizado foi o SIM808. Ademais, foram desenvolvidas outras partes auxiliares no circuito tais como: alimentação, proteção (sensor de temperatura) e interface com o usuário (LEDs e chave mecânica).

Assim, após um longo processo de testes em protoboard, com a elaboração do esquemático e do layout da placa de circuito impresso, foi obtido o layout do circuito (Figura 1). Depois disso, o circuito foi impresso e os componentes soldados

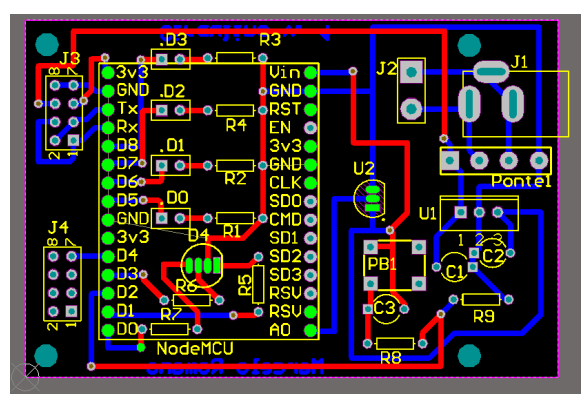

Figura 1. Layout PCB do circuito projetado.
Após essa etapa, foi elaborado o software a ser executado no ESP8266, que tinha como função principal ler a posição geográfica do SIM808 através de uma porta serial e transmiti-la para o servidor central como uma string (usando a comunicação $\mathrm{Wi}-\mathrm{Fi}$ ), contendo a posição geográfica do ônibus (latitude e longitude), e também os dados referentes à linha atual do Circular Interno, o número de satélites em uso e em vista e à temperatura atual do circuito. Como o projeto estava em validação, essa mensagem foi enviada para um servidor do próprio bolsista, hospedado na página ThingSpeak, como mostra a Figura 2. A Figura 3 ilustra o funcionamento do circuito projetado.

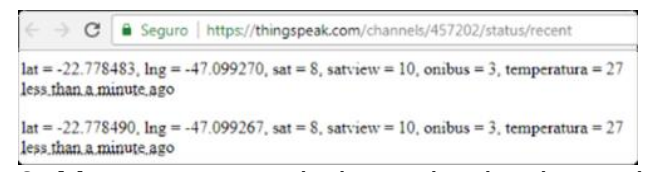

Figura 2. Mensagens enviadas pelo circuito projetado impressas na página ThingSpeak.

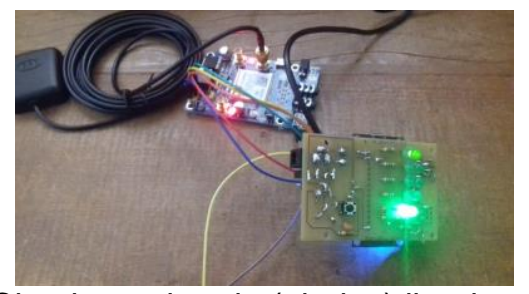

Figura 3. Circuito projetado (abaixo) ligado ao módulo SIM808 (acima) em funcionamento.

\section{Conclusões}

Conclui-se esse artigo atestando que o projeto foi realizado com êxito e possibilitou ao bolsista o aprendizado do processo de elaboração e projeto de uma placa de circuito impresso e também de programação em microcontroladores. A Prefeitura do Campus da Unicamp aprovou o projeto e pretende colocá-lo em prática assim que possível.

\section{Agradecimentos}

Agradecemos ao CNPq pelo apoio financeiro.

\footnotetext{
${ }^{1}$ https://nodemcu.readthedocs.io/en/master/en/\#nodemcu-documentation, acessado em 08/09/2017
} 